\title{
Potencjał społeczności lokalnych w rozwoju turystyki Żuławek
}

\section{The Potential of Local Communities in Tourism Development in Żuławki}

\author{
Małgorzata MARKS-KRZYSZKOWSKA ${ }^{1} \bullet$ Pamela JEZIORSKA-BIEL ${ }^{2}$ \\ Uniwersytet Łódzki \\ Wydział Ekonomiczno-Socjologiczny \\ ${ }^{1}$ Katedra Gospodarki Samorządu Terytorialnego \\ ul. Rewolucji 1905 r. 41, 90-214 Łódź \\ ${ }^{2}$ Katedra Geografii Regionalnej i Społecznej \\ ul. Kopcińskiego 31, 900-142 Łódź \\ malmarks@o2.pl•pamela.jeziorska@geo.uni.lodz.pl
}

Zarys treści: Celem artykułu jest identyfikacja potencjału społeczności lokalnej w rozwoju funkcji turystycznej wsi. Egzemplifikacją rozważań jest kreowanie rozwoju turystyki (szczególnie predestynowanej do turystyki wodnej) wsi Żuławki w gminie Stegna. Miejscowość posiada cenne walory krajobrazowo-przyrodnicze oraz dogodne usytuowanie przestrzenne. Szczególną jednak intencją autorek jest zwrócenie uwagi na proces aktywizowania się napływowej społeczności lokalnej na rzecz zrównoważonego rozwoju miejscowości. Jest on możliwy dzięki kształtującym się cechom potencjału tej społeczności, jak: poczucie wzajemnej integracji, zaangażowanie, umiejętność rozwiązywania problemów oraz dostęp do zasobów. Podmiotowość charakteryzowanej społeczności przejawiała się w zdolności adaptacji i identyfikacji z nowym miejscem zamieszkania i jego problemami, umiejętności artykulacji własnej wizji rozwoju wsi oraz aktywizacji otoczenia na rzecz realizacji ustalonych planów. Tekst opiera się na wynikach badań własnych autorek, przeprowadzonych w 2015 r. technikami obserwacji uczestniczącej i wywiadu swobodnego z lokalnymi aktywistami.

Słowa kluczowe: Żuławy, wieś, potencjał społeczności lokalnej, turystyka.

\section{Wprowadzenie}

Mimo że nie brakuje tez o globalizacji wypierającej lokalność i prowadzącej do zmierzchu społeczności lokalnych, istnieje także wiele dowodów na ich dalsze trwanie i rozwój. Zainteresowanie wspólnotą przejawia się zarówno w koncepcjach teoretycznych (np. komunitariańskich ${ }^{1}$ ), polityce rządzących, a także w działaniach lokalnych zbiorowości. W nowoczesnych koncepcjach rozwoju lokalnego dobitnie akcentuje się odejście od dominacji zewnętrznego-centralnego sterowania na rzecz silnych, autonomicznych i zintegrowanych społeczności lokalnych (Lewenstein 2006).

\footnotetext{
${ }^{1}$ Nurt współczesnej filozofii polityki, przeciwstawiany liberalizmowi, akcentujący ważność wspólnot w społecznym życiu człowieka.
} 
Zatem w samych wspólnotach pokłada się nadzieję na wsparcie lub zainicjowanie procesów rozwojowych. Są one postrzegane wręcz jako gwarant rozwoju (por. Etzioni 2012). Jednocześnie praktyka wskazuje, że nie wszystkie społeczności w oczekiwany sposób są gotowe do samoprzekształceń, różny jest też ich udział w tych procesach. Podstawowe pytanie brzmi zatem: czy współczesne społeczności lokalne są wyposażone w cechy, dzięki którym będą zdolne do rozwoju? Innymi słowy, czy posiadają potencjał, który może zostać wyzwolony na rzecz pozytywnych przemian?

Odpowiedzi na to pytanie mogą dostarczyć społeczności wiejskie. Po pierwsze, są one relatywnie dobrze rozpoznanym obiektem badań, po drugie, są popularyzowane przez dobre praktyki projektów aktywizacyjnych, finansowanych przez Unię Europejską. Oczywiście trudno szukać analogii współczesnych społeczności wiejskich do pierwotnych; dzisiejsza wieś znacząco różni się choćby od jej postaci z XIX w., podobnie jak funkcjonujące tam wspólnoty. One nadal trwają, zmieniają jedynie swój charakter, ewoluują. M. Wieruszewska (2014, s. 146) wskazuje na powielany błąd w postrzeganiu więzi społecznej jako „fenomenu przeszłości lub marginalnego przeżytku okresu przedmodernizacyjnego”. Więzi - elementarny czynnik decydujący o tożsamości społeczności lokalnych, nadal łączą mieszkańców wsi, choć często mają bardziej instrumentalny niż emocjonalny charakter. Jedną z przyczyn i jednocześnie cech współczesnych wiejskich wspólnot lokalnych jest otwarcie się na zewnętrzne wobec nich systemy.

Celem artykułu jest identyfikacja potencjału społeczności lokalnej wybranej wsi, który jest angażowany do rozwoju jej turystycznej funkcji, a także zwrócenie uwagi na proces aktywizowania się społeczności lokalnej na rzecz zrównoważonego rozwoju miejscowości. Impulsem do przygotowania niniejszego tekstu był udział autorek w projekcie aplikacyjno-badawczym, mającym na celu wyłonienie kilkudziesięciu najciekawszych, głównie pod kątem dziedzictwa architektoniczno-historycznego, wsi w Polsce ${ }^{2}$. Z analiz badaczek jednoznacznie wówczas wynikało, iż potencjał rozwojowy tkwił przede wszystkim w tkance społecznej badanych miejscowości (por. Jeziorska-Biel i Marks-Krzyszkowska 2017). Natomiast drugorzędną, choć także istotną rolę odgrywały pozostałe zasoby, np. architektoniczne, kulturowe, przyrodnicze itp.

Większość opracowań podejmujących problematykę potencjału lokalnego prowadzonych jest na poziomie gminy, rzadziej zaś w odniesieniu do wsi. Autorki proponują badanie potencjału na poziomie jednej miejscowości, dzięki czemu bezpośrednio odnoszą się do niewielkiej, lecz dobrze dającej się rozpoznać społeczności lokalnej. Do pogłębionych eksploracji wybrano wieś Żuławki położoną na obszarze Żuław Wiślanych. Tam też w lipcu 2015 r. przeprowadzono dwutygodniowe badania terenowe. Posłużono się wówczas techniką obserwacji uczestniczącej, uzupełnioną niestandaryzowanymi wywiadami swobodnymi z mieszkańcami wsi. Pozwoliła ona skonfrontować wiedzę uzyskaną od przedstawicieli miejscowości z praktyką i życiem codziennym mieszkańców badanej wsi, a także rozpoznać możliwości korzystania z usług turystycznych świadczonych przez mieszkańców - z perspektywy potencjalnego turysty. Osoby, z którymi przeprowadzono rozmowy to lokalni działacze: sołtys, radna, przedstawicielka koła kobiet, mieszkańcy, przedsiębiorcy.

2 Projekt Sieć Najciekawszych Wsi realizowany był w okresie 16.01-31.05.2015 r na zlecenie Fundacji Programów Pomocy dla Rolnictwa, pod merytorycznym i organizacyjnym kierownictwem dr hab. Marcina Wójcika, na próbie 50 wsi w Polsce (por. Wójcik 2016). 


\section{Potencjał społeczności lokalnej - założenia teoretyczne}

Kluczowym pojęciem w prowadzonych rozważaniach jest potencjał społeczności lokalnej ${ }^{3}$. Rozumiany jest jako sprawność w określonej dziedzinie lub tkwiący w kimś albo w czymś zasób możliwości czy zdolności. Synonimami potencjału mogą być zatem m.in.: możliwości, zdolności, wydolność, sprawność, efektywność, wydajność, produkcyjność, prężność, moc, żywotność, a także zasoby (Broniarek 2005). Rozumienie terminu społeczność lokalna autorki przyjęły za P. Starostą (1995, s. 30), wg którego jest to określony typ struktury społeczno-przestrzennej, który tworzą terytorium definiujące jedno skupisko ludności charakteryzującej się pewnym stopniem powiązań, zależności i instytucji oraz psychicznym zespoleniem z tą strukturą. Potencjał społeczności jest zatem pewną cechą - specyficzną zdolnością wspólnoty, która może być wykorzystana do osiągnięcia (przez nią) ważnego dla niej celu.

Jak zauważają R.J.Chaskin i in. (2001, 2007), potencjał powstaje zarówno w wyniku formalnych, jak i nieformalnych interakcji, dokonujących się między kapitałem ludzkim, społecznym i zasobami tej społeczności. Wspomniani autorzy, dokonując przeglądu istniejących definicji, wyselekcjonowali najczęściej występujące elementy składowe tego pojęcia. Stanowią je: szeroko rozumiane zasoby (ludzkie, rzeczowe, finansowe itp.), sieci relacji, przywództwo i wsparcie procesów angażowania się społeczności we wspólne działania. Jednocześnie cytowani badacze proponują, by potencjał społeczności lokalnej analizować z perspektywy kilku wzajemnie przenikających się wymiarów, takich jak: cechy charakteryzujące wybraną społeczność, działania społeczne, funkcje/role przypisane potencjałowi, strategie działania, uwarunkowania środowiskowe i rezultat, do których potencjał ma doprowadzić. Krótka charakterystyka każdego z aspektów pozwoli wydobyć najważniejsze elementy potencjału, do których autorki (w kolejnych podrozdziałach tekstu) będą poszukiwały odniesienia i analogii w badanej społeczności Żuławek.

Na cechy charakteryzujące potencjał społeczności, które jednocześnie stanowią podstawę aktywności lokalnej, składają się: poczucie tożsamości/identyfikacji ze społecznością lokalną, angażowanie się członków we wspólne sprawy, umiejętność rozwiązywania problemów i dostęp do zasobów. Ich wartości są stopniowalne i by móc osiągnąć wyznaczone cele, prawdopodobnie konieczne jest (jak przypuszczają cytowani wcześniej autorzy), aby niektóre z nich osiągały określony minimalny (progowy) poziom4 . Jednocześnie społeczność może którejś z cech nie posiadać.

Identyfikacja z miejscem zamieszkania jest jednym z aspektów więzi lokalnej. Świadczy o poczuciu bliskości między mieszkańcami, podzielaniu wspólnych wartości norm i wizji, a także uznaniu wzajemnego wpływu na tworzenie warunków życia (Chaskin i in. 2007, za: McMillan i Chavis 1986). Z perspektywy socjologicznej emocjonalne utożsamianie się może odnosić się do osoby lub grupy osób, roli społecznej ${ }^{5}$. Działanie społeczności lokalnej nie zawsze musi wynikać z więzi emocjonalnej. Dzieje się tak, gdy ludzie są w sta-

${ }^{3}$ Autorki celowo ograniczyły się do jednej, lecz kompleksowo wyczerpującej problematykę, perspektywy teoretycznej zaczerpniętej z książki R.J Chaskina i in. (2001). Fragmenty tej pozycji, wykorzystane w niniejszym tekście, zostały przetłumaczone na język polski i zamieszczone w książce pod redakcją T. Kazimierczaka (2007).

${ }^{4}$ Cytowani autorzy nie zaproponowali jednak ich konkretnych wartości.

${ }^{5}$ Z jednej strony może być identyfikacją z wyboru (np. gdy preferujemy jedną społeczność nad inną, chcemy przebywać w miejscu zamieszkania i nie chcemy jej opuścić, a także interesujemy się sprawami lokalnymi), z drugiej zaś z przymusu (np. spauperyzowanych grup, które budują tożsamość na bazie przymusowej lokalizacji, jak mieszkańcy osiedli popegeerowskich) (por. Michalska-Żyła 2010). 
nie korzystać z zewnętrznych zasobów (rozwijają powiązania z szerszymi systemami), nie są wówczas zakorzenieni w codziennych kontaktach z sąsiadami, rodziną czy znajomymi, jednak podejmują wspólnotowe działania. Więzi mają wówczas charakter instrumentalny. Zazwyczaj identyfikacja z sąsiedztwem czy społecznością lokalną jest znacznie silniejsza niż z większymi zbiorowościami. Zaangażowanie we wspólne działania jest natomiast konsekwencją poczucia odpowiedzialności za to, co dzieje się w społeczności. Warunkiem koniecznym jest wówczas poczucie podmiotowości, tj. postrzeganie siebie jako udziałowca wnoszącego wkład w dobro wspólne lub przynajmniej chęć uczestnictwa jako udziałowca (Chaskin i in. 2007).

Umiejętność rozwiązywania problemów to z kolei realne przełożenie zaangażowania na konkretne działanie. Cecha ta nie zawsze musi być uzależniona od charyzmy czy też znaczącego wpływu lidera. Autorzy podkreślają, że ważne jest wypracowanie trwałych i odpowiednio licznych mechanizmów postępowania, które zadziałają nawet w przypadku braku lidera i dostosują się do pojawiających się wyzwań otoczenia.

Kolejną cechą charakteryzującą potencjał społeczności lokalnej jest dostęp do zasobów - możliwości korzystania zarówno z endogennych, jak i egzogennych zasobów ekonomicznych, ludzkich, materialnych czy politycznych. Do tej listy warto dołączyć informację - bardzo cenny zasób współczesnego życia społeczno-gospodarczego. Działania społeczne podejmowane przez członków społeczności mogą odbywać się na trzech różnych poziomach: jednostek, organizacji i sieci stowarzyszeń ${ }^{6}$. Na poziomie działania jednostki istotną rolę pełnią kapitał ludzki i przywództwo lidera. Czynniki te mają bowiem znaczenie w inicjowaniu przedsięwzięć i mobilizowaniu innych. Na poziomie organizacyjnym potencjał społeczności przejawia się w umiejętności (różnego typu grup i podmiotów nie zawsze formalnych) wypełniania swoich funkcji w odpowiedzi na potrzeby społeczności. Na poziomie sieci współdziałania potencjał rozpatrywany jest z perspektywy kapitału społecznego, czyli sieci relacji, które łączą ludzi, budują między nimi zaufanie, dają wsparcie i podtrzymują zasadę równego dostępu do zasobów (Chaskin i in. 2007, s. 56, za: Coleman 1988; Putnam 1993). Współcześnie coraz większego znaczenia nabiera funkcjonowanie na pograniczu różnych sieci. Sprzyja ono bowiem skutecznym negocjacjom, zwiększa dostęp do zasobów i kontrolę nad ich wykorzystaniem, poszerza wachlarz nowych możliwości, a zatem wspomaga tworzenie i działanie potencjału społeczności.

Istotne znaczenie dla budowania potencjału mogą mieć tzw. strategie, czyli pewnego typu elementy organizacyjne, przyśpieszające rozwój potencjału, jak np. przywództwo (tu rozumiane jako przygotowanie liderów), rozwój organizacyjny (tworzenie nowych i rozwój istniejących organizacji), organizowanie się społeczności (mobilizowanie interesariuszy do działań wspólnotowych), współpraca między organizacjami (rozwój relacji i współpracujących ze sobą partnerstw).

Równie ważnym elementem są uwarunkowania środowiskowe rozumiane przez Chaskina i pozostałych autorów jako okoliczności pośredniczące, sprzyjające lub utrudniające rozwój potencjału. Są to np. czynniki geograficzne, makrostrukturalne, systemowe. Szczególną rolę należy także przypisać, pominiętym w cytowanym tekście, czynnikom historycznym, które mogą wpływać zarówno na poczucie tożsamości, identyfikacji ze wspólnotą, jak również przez lata kształtować postawy prospołeczne, obywatelskie.

\footnotetext{
${ }^{6}$ Zdaniem cytowanych autorów potencjał może funkcjonować równocześnie na więcej niż jednym poziomie.
} 
Funkcje to inaczej specyficzne zastosowanie, zadanie, jakie społeczność może wykonać dzięki temu, że posiada potencjał. Cel, wokół którego angażowany jest potencjał, może być różnie zdefiniowany, w zależności od potrzeb grupy. Funkcje prowadzą do osiągnięcia konkretnych rezultatów. Rezultaty zaś definiowane są jako uzyskanie pożądanych efektów podejmowanych działań.

Przytoczone wyżej spojrzenie na potencjał społeczności lokalnej pozwala stwierdzić, że jego trzon stanowią skoncentrowane zdolności do jej organizacji i rozwoju. Umożliwiają one bezpośrednie kontakty, dobrą znajomość i wymianę informacji, a także synergiczne wykorzystanie zasobów. Zwykle odnoszą się do konkretnej przestrzeni i jej dotyczą. Możliwości te nie ograniczają się wyłącznie do lokalnych zasobów, są powiązane, uzupełniane i zasilane elementami dalszego otoczenia, większych wobec społeczności systemów (np. województwa, państwa itp.). Cele mogą być różnie zdefiniowane i zależą od potrzeb, np. przetrwanie, adaptacja czy rozwój. Potencjał nie ma charakteru trwałego, zmienia się i kształtuje, np. w zależności od liczby członków społeczności, ich cech psychospołecznych, tworzonych organizacji itd.

\section{Żuławy Wiślane - krajobraz i trudne losy mieszkańców a poczucie tożsamości}

Charakteryzując miejscowość Żuławki, należy koniecznie odnieść się do jej położenia w szerszym kontekście, tj. Żuław Wiślanych7. Poznanie bowiem procesów zarówno naturalnych, jak i społecznych zachodzących na tym terenie tworzy tło, bez znajomości którego trudno zrozumieć specyfikę tej miejscowości. Namiastkę wszystkich cech charakteryzujących Żuławy Wiślane można bowiem odnaleźć w Żuławkach, inaczej ujmując - historia Żuław to historia samych Żuławek.

Specyfika przestrzenna Żuław Wiślanych polega przede wszystkim na otwartym krajobrazie - co ważne i unikatowe - całkowicie ukształtowanym przez człowieka, będącym wyłącznie wytworem kulturowym (a nie pierwotnym czy naturalnym). Nie oznacza to jednak, że jest nieharmonijny czy zdegradowany ludzką działalnością. Wręcz przeciwnie, w znakomitej części zachowuje bogactwo form zagospodarowania minionych okresów, jest nasycony różnorodnymi elementami wielokulturowego dziedzictwa architektonicznego i inżynierskiego. Do dziś zachowała się także wiodąca - rolnicza - funkcja tych terenów. Zatem, jak podkreśla B. Lipińska (2011, s. 8), Żuławy Wiślane „są obszarem szczególnie predysponowanym do świadomych działań kształtujących - także poprzez ochronę najcenniejszych historycznie cech i właściwości krajobrazu".

Historia osadnictwa na terenie Żuław sięga okresu panowania Zakonu Krzyżackiego. Mimo negatywnych stereotypów i skojarzeń z działalnością krzyżacką można spotkać się na Żuławach z pozytywnymi ocenami działalności Zakonu. Dotyczą one przemyślanych i skoordynowanych prób zagospodarowania przestrzeni, a przede wszystkim sprowadzenia na ten teren osadników holenderskich, którzy posiadali doświadczenie i wiedzę w zakresie zagospodarowywania terenów podmokłych i z powodzeniem wdrażali pierwsze

\footnotetext{
7 Powstanie Żuław Wiślanych wiąże się z deltotwórczą działalnością rzeki Wisły. Naturalny proces nanoszenia utworów rzecznych w głąb lądu zakończył się pod koniec XIII w. i od tego czasu rozpoczął się proces osadnictwa na tych terenach. Współcześnie jest to rozległy, całkowicie równinny teren z jednocześnie występującymi obszarami depresyjnymi, bogatą i uregulowaną siecią wodną (rzek, kanałów) i bardzo żyznymi glebami. Bezpośrednie sąsiedztwo wód morskich, ujście rzeki Wisły i sieć licznych kanałów i rzek sprawiają, że jest to teren podmokły i bardzo często nawiedzany przez powodzie.
} 
innowacje ujarzmiające żywiołową przyrodę. W połowie XV w. tereny te zaczęły podlegać religijnie tolerancyjnemu władztwu państwa polskiego, co sprzyjało intensywnemu napływowi (w XVI w.) prześladowanych w Niderlandach menonitów. Nowi osadnicy szybko dostosowali się do trudnych warunków ziemi żuławskiej, przyczyniając się do znacznego jej rozwoju. Bezpieczeństwo i swobody religijne zostały jednak zagrożone w chwili przejścia Żuław pod zabór pruski. Nietolerancyjny zaborca doprowadził do znacznego ubytku (migracje do Rosji, nad Morze Czarne) ludności menonickiej lub do zmiany przez nią wyznania na ewangelickie. Najtrudniejszym, wręcz krytycznym momentem dla ludności żuławskiej był jednak koniec II wojny światowej związany z przymusowym wysiedleniem i niemal całkowitym pozbyciem się z tego terenu autochtonów. Ponadto zimą 1945 r. broniące się przed Rosjanami wojska niemieckie wysadziły w powietrze wały wiślane, całkowicie zalewając i niszcząc blisko 600-letni dorobek mieszkańców Żuław.

Po II wojnie światowej, w wyniku zarówno autonomicznych decyzji, jak i przymusowych przesiedleń, Żuławy ponownie zostały zasiedlone, tym razem jednak ludnością pochodzącą z Kresów Wschodnich, środkowej i południowo-wschodniej Polski. Świadome, indywidualne decyzje przeprowadzki na te tereny wynikały głównie z kalkulacji ekonomicznych. Mieszkańcy, którzy rozmawiali ze starszymi ludźmi pamiętającymi czasy powojenne, podkreślali, że zaraz po wojnie, migrowano tu także całkiem świadomie: „tu były w niezłym stanie technicznym gospodarstwa, a ziemia była doskonała. W tamtym czasie na 20 ha można było dobrze gospodarzyć. Dziś z 50 ha trudno wyżyć". Inni byli zmuszeni żyć i gospodarować na tych ziemiach. „Tu ludzi pociągami przywozili” - opowiadała jedna z respondentek, „jesteśmy zewsząd” - mówiła inna. Konsekwencją swoistego „wymieszania kulturowego" była różnorodność wzorców i praktykowanych tradycji społeczno-gospodarskich, co ma istotne znacznie dla współczesnej społeczności. Nie bez znaczenia jest, iż kolejni nowoosadnicy, w przeciwieństwie do poprzedników, nie tylko nie mieli wiedzy o gospodarowaniu na tym żyznym, lecz bardzo wymagającym terenie, ale także często prezentowali postawy bierne i niechętne wobec nowego miejsca do życia, traktowali je jako przejściowe i tymczasowe. Nie było to miejsce tworzone przez nich i dla nich, lecz obce i nieznane, często także niechciane. Takie czynniki jak brak więzi z nowym miejscem zamieszkania, brak wspólnych tradycji kulturowych (na bazie których tę więź można tworzyć), centralnie sterowana polityka lokalna doprowadziły do swoistego „marnotrawstwa możliwości ziemi żuławskiej i jej piękna" (Lipińska 2011, s. 31) ${ }^{8}$.

Opisane wyżej wydarzenia powojenne przyniosły całkowitą zmianę charakteru społecznego Żuław. Przerwana została ciągłość tradycji, całkowicie zmienił się skład społeczny. Jak podkreśla B. Lipińska (2011, s. 45): „nie istnieje bowiem jej podstawowy składnik i czynnik napędowy - człowiek, mieszkaniec, twórca, który od wielu pokoleń był związany z tą ziemią. (...) Nie istnieje dawna, tradycyjna, skonsolidowana zbiorowość ludzka i jej pamięć, dzięki której Żuławy Wiślane stały się w ciągu stuleci jednolitym, zintegrowanym, sprawnie działającym organizmem. (...) Tradycja kulturowa Żuław Wiślanych straciła swą społeczną bazę i ciągłość, stając się tradycją martwą, opartą jedynie na zewnętrznych, formalnych przejawach, bez żywej, twórczej treści". Cytowana autorka dostrzega jednak zalążki kształtowania się poczucia wspólnoty wśród nowych mieszkańców, zwłaszcza w sy-

8 Polemizując z cytowaną autorką, można zaryzykować stwierdzenie, że brak inwestycji i zainteresowania tym terenem przyczyniło się paradoksalnie do zachowania przynajmniej w części niezmienionego krajobrazu (brak dużych firm, żywiołowego mieszkalnictwa, urbanizacji itp.). Degradacja zaś dziedzictwa kultury materialnej w innych częściach Polski postępowała w podobnym zakresie. 
tuacjach zagrożenia np. powodziami (wpływu środowiska żuławskiego). Przeprowadzone przez autorki badania potwierdzają tę tezę. Wspólnota żuławska tworzyła się w sytuacji zagrożenia, choć niepochodzącego ze strony natury i przyrody, lecz z innych źródeł - ludzi (obcych) pragnących na swój użytek przekształcić wspólnie użytkowaną przestrzeń. Jak pisze wspomniana autorka, „dopiero wspólne działanie ludzi mających te same cele, dążenia, interesy i zamierzenia, potrafi stworzyć nawet na wielkich obszarach harmonijną całość" (Lipińska 2011, s. 45).

\section{Żuławki - zasoby przestrzeni w ofercie turystycznej}

Miejscowość Żuławki usytuowana jest w części Prawobrzeżnych Żuław Wiślanych, natomiast administracyjnie stanowi jedno z sołectw położonej w pasie nadmorskim gminy Stegna w województwie pomorskim. Żuławki same nie leżą bezpośrednio nad morzem, oddalone są od niego o ok. $5 \mathrm{~km}$. Taka lokalizacja potencjalnie może także stanowić atut miejscowości, zwłaszcza w kontekście rozwoju funkcji turystycznej. Niski poziom urbanizacji wsi i okolic wydaje się wadą, jednak w tzw. „zapóźnieniu cywilizacyjnym” można upatrywać zaletę. Wieś bowiem nie jest zatłoczona przez masowych turystów, z czym można mieć do czynienia już o $5 \mathrm{~km}$ oddalonym Mikoszewie. O relatywnie dobrym usytuowaniu świadczy również sąsiedztwo większych, ciekawych turystycznie ośrodków miejskich: Gdańska, Elbląga czy Malborka.

Wzdłuż wsi płynie rzeka Szkarpawa - jeden z głównych zasobów i jednocześnie atutów miejscowości. Rzeka wlicza się w poczet dróg wodnych tworzących Pętlę Żuław ${ }^{9}$, ma długość 25,4 km i jest w całości spławna, co znakomicie wzmacnia szanse rozwoju turystyki wodnej. Szkarpawa niesie ze sobą czyste wody, które sprzyjają rozwojowi bogatej flory i fauny (raki, żółwie, zaskrońce, czaple białe i siwe, orły, kormorany, bobry itp.). W przeszłości rzeką odbywał się transport wodny, umożliwiając mieszkańcom komunikację z otoczeniem. Jak wspomina jeden z respondentów:

"(...) tutaj chodził taki parostatek, zbierał babcie z jajkami, o 4 rano wypływał z Rybiny, o 8 był na targu w Gdańsku, popołudniu wracał. Dziś jest to nie do zrobienia, bo w takim Sobieszewie most jest otwierany 3-4 razy na dobę i tylko dla turystów".

Szkarpawa stanowi podstawę, bazę rozwoju turystyki wodnej Żuławek. Z rzeką związana jest także śluza „Gdańska Głowa” - to ciekawy hydrotechniczny obiekt, stanowiący potencjalną atrakcję turystyczną ${ }^{10}$. Zbudowano ją w ramach przekopania ujścia Wisły w 1895 r., co pozwoliło regulować poziom wody na Szkarpawie, a także umożliwiło powrót ruchu statków i barek. Wzdłuż wału rzecznego mieszkańcy planują wytyczenie szlaku spacerowo-rowerowego, co uatrakcyjni miejscowość turystycznie i znacznie poprawi bezpieczeństwo na drodze.

\footnotetext{
9 Pętla Żuławska to ciekawy nowy produkt turystyki wodnej Żuław. Tworzy go sieć dróg wodnych Wisły, Martwej Wisły, Szkarpawy, Wisły Królewieckiej, Nogatu, Wisły Śmiałej, Wielkiej Świętej - Tugi, Motławy, Kanału Jagiellońskiego, rzeki Elbląg i Pasłęki, a także wody Zalewu Wiślanego. Łącznie 303 km, 11 przystani, mieszczących się na terenach 7 gmin. Atrakcja powstała dzięki funduszom europejskim. W chwili obecnej jest stosunkowo mało znana, lecz z roku na rok przyciągająca coraz więcej turystów.

${ }_{10}$ W XVII w. mieścił się w tym miejscu posterunek obronny Gdańska. Twierdza została jednak rozebrana z powodu przeprowadzenia przekopu Wisły.
} 


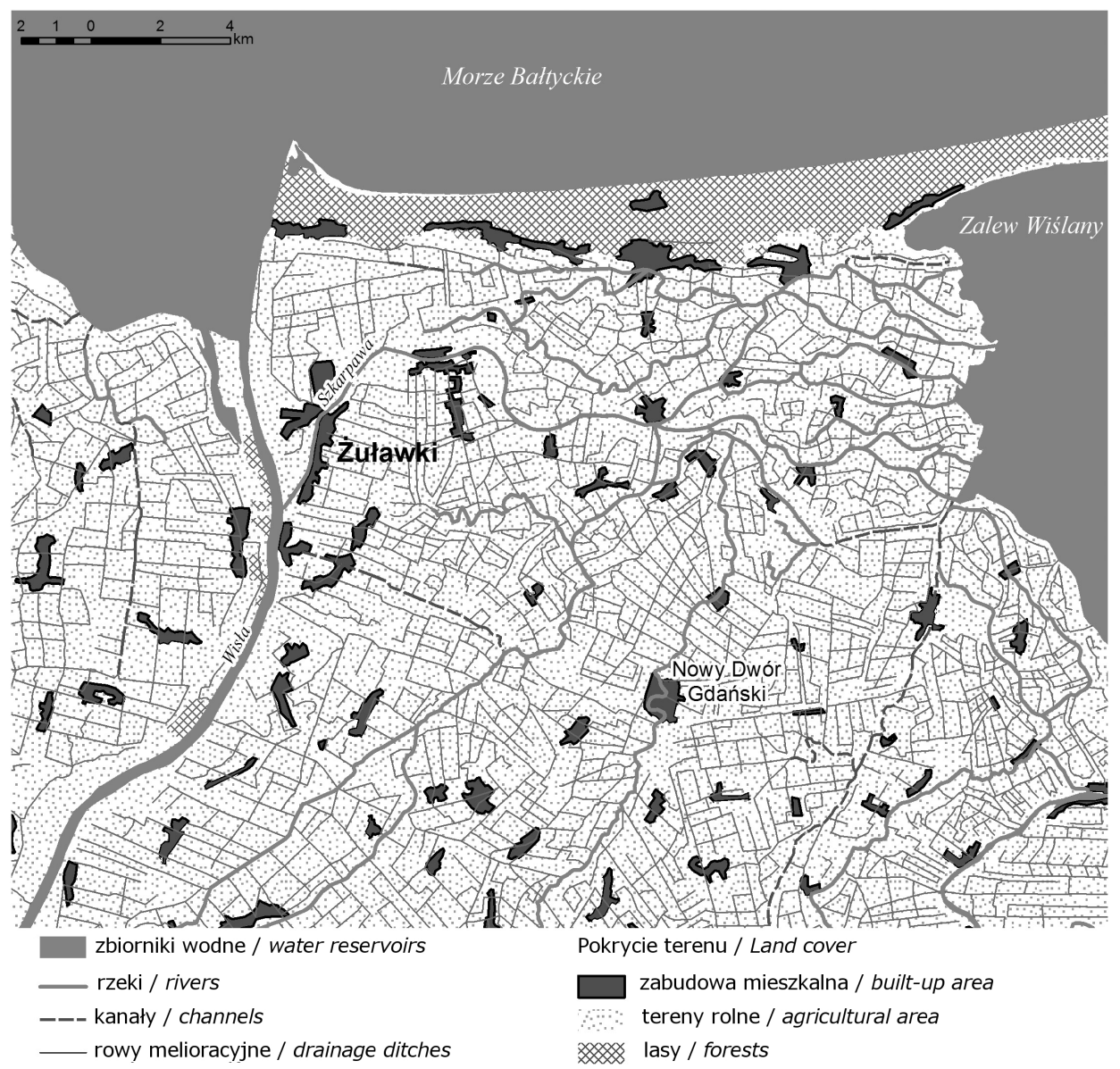

Ryc. 1. Żuławki - położenie i otaczający krajobraz Źródło: opracowanie Karoliny Dmochowskiej-Dudek. Żuławki-location and landscape Source: study by Karolina Dmochowska-Dudek.

Dawni mieszkańcy Żuław (menonici) wprowadzili na te tereny charakterystyczne formy budownictwa, jak np. domy podcieniowe ${ }^{11}$. Część z tych obiektów przetrwała do dnia dzisiejszego. Stanowią one bardzo cenny zabytek. Współcześnie Żuławki łącznie z Drewnicą (sąsiednią wsią) posiadają jeden z najlepiej zachowanych zespołów ruralistycznych: ok. 200 budynków objętych ochroną, w tym ok. 80 w samych Żuławkach. Problemem jednak jest ich stan. Dewastacja starej zabudowy jest znacząca, do czego przyczynia się brak środków finansowych mieszkańców na remont bądź też brak poczucia estetyki i dbałości o te obiekty. Znajdują się one pod nadzorem konserwatora zabytków i wszelka ingerencja w ich stan wymaga jego zgody, a koszty remontu są znacznie wyższe od

11 Budynki (z lat 1780-1850) stawiano na zlecenie Wolnego Miasta Gdańska dla osadników holenderskich i wedle ich oczekiwań. Charakteryzują się bardzo ciekawą konstrukcją: główny trzon budynku jest murowany, zaś reszta z drewna, posiadają tzw. ślepą kuchnię i sień, z której jest bezpośrednie wejście do pięciu pomieszczeń obok siebie (drzwi koło drzwi). 
przeciętnych. Równolegle procesowi dewastacji towarzyszy, choć w znacznie mniejszym stopniu, zjawisko odnawiania starych, ponad 200 letnich budynków. Nowi właściciele, świadomi wartości historycznej, inwestują w domy i modernizują je, choć jak mówi jeden z nich: „ciężko żyje się pod nadzorem konserwatora”. Obecnie na terenie Żuławek znajduje się 5 odnowionych starych domów podcieniowych. Stanowią one najbardziej charakterystyczne i unikalne zasoby turystyczne wsi. W jednym z nich zostanie otwarte prywatne mini muzeum. Ponadto walorem architektonicznym są zagrody holenderskie, które także stanowią spuściznę osadnictwa niderlandzkiego ${ }^{12}$. Na uwagę turysty zasługuje również stary menonicki cmentarz wraz z neogotycką kaplicą. Jest on kolejnym elementem dziedzictwa historycznego tych terenów, niestety najbardziej zaniedbanym. Potomkowie pochowanych tam osób rzadko odwiedzają to miejsce, a nowowosadnicy nie czują z nim żadnej więzi.

Ciekawostkę stanowi usytuowany w centrum kompleks parkowo-stawowy, który uatrakcyjnia przestrzeń wsi. Stwarza on swoisty azyl, nie tylko dla turystów, ale również dla mieszkańców i stanowi główne miejsce organizacji lokalnych imprez. Mankamentem jest jednak jego niezagospodarowanie. Plany modernizacji parku społeczność ma już od dawna, a wprowadzenie ich w życie jest kwestią czasu. Mieszkańcy zadeklarowali przeznaczyć kilka kolejnych transzy z funduszu sołeckiego na ten właśnie cel. Niemal po przeciwległej stronie zlokalizowana jest świetlica wiejska z zadbanym, dobrze wyposażonym i otwartym dla turystów placem zabaw. Są to miejsca wyremontowane i samodzielnie urządzone przez mieszkańców. Świetlica pełni centrum aktywności kulturalnej wsi. Społeczność organizuje w niej koncerty, zajęcia dla dzieci oraz różnego typu spotkania integracyjne. Wymienione wyżej działania są potwierdzeniem angażowania się członków wsi we wspólne sprawy - kolejnej cechy charakteryzującej potencjał społeczności lokalnej.

Przy przeciwległym brzegu Szkarpawy położona jest miejscowość Drewnica, która administracyjnie jest odrębnym sołectwem, natomiast dla mieszkańców Żuławki „to jeden organizm z Drewnicą". Rozmówcy traktują obie wsie jak jedną całość, np. przedstawiając ofertę pobytową Żuławek mówią często o infrastrukturze Drewnicy:

„Żuławki są pod względem miejsca zatrzymania bardzo atrakcyjne, bo blisko jest apteka, policja, poczta, (wszystkie te instytucje są wyłącznie w Drewnicy - podkr. aut.), sklepy".

Także z perspektywy turysty, różnica między obiema miejscowościami zaciera się, mimo iż, aby przejść z jednej do drugiej, trzeba pokonać zwodzony most, który sam w sobie jest także atrakcją turystyczną.

Infrastruktura gastronomiczna i noclegowa to kolejny ważny, a wręcz niezbędny element oferty turystycznej. Jedną z największych słabości w tym zakresie jest całkowity brak usług gastronomicznych (z wyjątkiem oferty świadczonej dla gości gospodarstwa agroturystycznego). Mieszkańcy mają tego pełną świadomość i w przyszłości chcieliby zaadoptować na ten cel budynek starej serowarni. Jednocześnie wieś dysponuje znacznym potencjałem kulinarnym. Tkwi on w wielokulturowej tradycji mieszkańców pochodzących z różnych części kraju. Nie ma tu jednej charakterystycznej dla Żuławek potrawy. Dlatego pojawiła się propozycja organizowania przeglądów, festiwali podobnych potraw, przygotowywanych jednak w nieco inny sposób ze względu na kulinarne tradycje regio-

12 Zagrodę stanowił dom mieszkalny, obora i stodoła łączące się ze sobą szczytami - jeden ciąg o funkcjach mieszkalnych i gospodarczych. 
nów, z których pochodzą obecni mieszkańcy. Obiekty gastronomiczne (smażalnie, restauracje, wędzarnie) koncentrują się w pasie nadmorskim. Obecnie jedną z atrakcji pobytu w Żuławkach może być właśnie wyprawa łodzią do sprawdzonej lokalnej nadmorskiej gastronomii:

„My stąd płyniemy łódką do Kątów Rybackich, do zaprzyjaźnionych wędzarni i tam możemy zjeść ciepłą rybkę".

We wsi nie ma obiektu świadczącego wysokiej klasy noclegi, co wynika z kalkulacji ekonomicznej potencjalnych inwestorów. Jak zauważa respondent:

„Te same pieniądze zainwestowane w pasie nadmorskim przyniosą nieporównywalnie większe zyski. Zainwestowanie tu będzie miało czas zwrotu nieporównywalnie dłuższy".

Taki stan, zdaniem wielu mieszkańców, należy utrzymać. Nie chcą oni bowiem stać się kolejną obleganą przez masowego turystę miejscowością. Ich motto to: cisza, spokój i przyroda. Taką właśnie ofertę pobytową obecnie stwarza, położona na uboczu wsi, prywatna przystań na Szkarpawie:

„Młodzież przelatuje szybciutko, ale są stali klienci, którzy śpiewają szanty, sami gotują i tworzą niepowtarzalną atmosferę".

Jest to jedyne takie miejsce we wsi, gdzie żeglarze pływający po Szkarpawie mogą skorzystać z WC, prysznica czy podłączenia do prądu. Przystań stwarza dla turysty okazję dotarcia do Żuławek szlakiem wodnym i skorzystania z oferty wsi. W miejscowości brak jednak informacji promującej to miejsce. Jest to działanie celowe i dobrze przemyślane. Latem dla przepływających przez Żuławki wystawiana jest informacja w formie piktogramów o możliwości dokonania naprawy, zjedzenia, zakupów. Poza tym oferta rozpowszechniana jest głównie w środowisku żeglarskim (np. na stronie www.porty24.pl). Z założenia wiedza o przystani ma dotrzeć do tzw. spokojnych turystów. Obecnie ok. 20-30\% z nich stanowią klienci niemieccy, którzy lubią pływać po tych terenach. Właściciel zna języki obce i posiada dobrze przygotowane materiały o Pętli Żuławskiej. Ze względu na ograniczony niewielki teren przystań nie obsługuje większej liczby turystów, obecnie mieści się tam ok. 10 łodzi. Przepisy związane z uzyskaniem pozwoleń wodno-prawnych są bardzo rygorystyczne, co powoduje że port nie może się bardziej rozwinąć. Jest to zatem mała przystań, ale o dużym uroku. Klimat tego miejsca wzmacnia ciekawa postać serdecznego i kulturalnego właściciela.

W koncepcję poszukiwania spokojnego turysty wpisuje się także oferta całorocznego wynajmu domków letniskowych. W ogłoszeniu reklamowym czytamy: „Domy Pod Wierzbami usytuowane są przy bocznej drodze, z daleka od hałasów. Z trzech stron otoczone są polami, sadem i linią wierzb. To idealne miejsce by wyciszyć się i zrelaksować". W chwili realizacji badań były to jedyne, poza gospodarstwem agroturystycznym, obiekty noclegowe we wsi. Latem w pobliżu rzeki funkcjonuje wypożyczalnia sprzętu wodnego (kajaki, rowery wodne) - produkt turystyczny adresowany do zupełnie innego turysty niż wspomniana wcześniej przystań. Miejsce to jest dobrze rozreklamowane i posiada ciekawą ofertę. 
Codzienna komunikacja mieszkańców wsi z otoczeniem odbywa się drogą lądową, głównie bardzo ruchliwą trasą powiatową, którą regularnie, z dużą częstotliwością kursują autobusy PKS. W chwili prowadzenia badań istniały plany jej przebudowy oraz wybudowania ścieżki rowerowej, bowiem brak bezpiecznych tras rowerowych przy jednoczesnym dużym natężeniu ruchu samochodowego stanowią istotne bariery rozwoju wsi.

Jednym ze sposobów komunikacji dawnych mieszkańców Żuławek była kolejka wąskotorowa, dziś niestety niedocierająca do miejscowości, lecz pozostająca w pamięci mieszkańców:

„Jeszcze do niedawna starsi ludzie opowiadali, jak to dawniej wieś wyglądała, kiedy nie było asfaltu, były koleiny w żuławskich drogach, jedynym środkiem lokomocji była kolejka wąskotorowa - po to ją zbudowano, by wywozić buraki cukrowe. Jeździło się głównie tą kolejką".

Dziś niestety kolejka omija Żuławki i trzeba przyznać, że dzieje się to z wielką stratą dla tej miejscowości.

\section{Mieszkańcy - potencjał rozwojowy wsi}

Żuławki do 1945 r. znane były pod nazwą Fürstenwerder. Datę lokacji tej miejscowości szacuje się na rok 1352. Była to wówczas wieś kmiecia, z około 20 siedliskami, zlokalizowana nad prawym brzegiem rzeki Szkarpawy (Lipińska 2011). Obecnie pełni funkcję rolniczą z coraz większym udziałem funkcji mieszkaniowej. Sołectwo Żuławki, liczące obecnie 593 mieszkańców, składa się z dwóch miejscowości: Żuławki i Żuławki Książęce ${ }^{13}$. Pierwszą grupą mieszkańców, dotychczas najliczniejszą (bowiem po II wojnie światowej we wsi pozostało zaledwie 5-6 autochtonicznych rodzin) są potomkowie osadników powojennych. Mimo iż coraz silniej utożsamiają się oni z tym miejscem, angażują na rzecz jego rozwoju, wciąż identyfikują się jako napływowi. Drugie lub trzecie pokolenie w rozmowach wyraźnie akcentuje, że ich rodziny "nie są stąd”, "tu wszyscy są napływowi, z autochtonów nie ma nikogo".

W miejscowości Żuławki wyraźnie odczuwa się napływ nowych mieszkańców, zwłaszcza spacerując uliczkami osiedli domków jednorodzinnych. Zdaniem respondentów, ok. 30\% zabudowań stanowią nowe domy. Są one własnością kolejnej (trzeciej) już w historii tego miejsca, fali nowoosadników - ludności miejskiej, poszukującej nowego, lepszego miejsca do życia. Wg szacunków naszych rozmówców, spośród nowych mieszkańców aż 90\% zdecydowało się na Żuławy, aby żyć w ciszy i w otoczeniu niezdewastowanej przyrody. Respondenci mają pełną świadomość wyboru Żuławek jako miejsca spokojnego, cichego o niezniszczonym krajobrazie. Zjawisko migracji z miasta na wieś jest charakterystyczne dla współczesnej, XXI-wiecznej Polski. W tym aspekcie rozmówcy często przeciwstawiają Żuławy Kaszubom:

„Z Trójmiasta główny kierunek budownictwa jednorodzinnego to Kaszuby, tam krajobraz jest absolutnie zniszczony. Polskie prawo pozwala na tworzenie siedlisk. (...) Na Kaszubach gęstość zabudowy jest nieporównanie większa, rozdrobnienie pól duże (tam nie było PGR-ów) ".

13 Jest to tzw. enklawa popegeerowska. 
Z rozmów wynikało, iż współcześnie na terenie wsi i gminy pojawia jeszcze jedna grupa nowoosadników, z tym że najczęściej w kontekście obaw i zagrożenia płynącego z ich strony:

„Tu były olbrzymie PGR-y i nie zostały one rozparcelowane, większość rolników (...) boi się możliwości wykupu ziemi przez obcokrajowców. W tej chwili duże gospodarstwa to kapitał całkiem zagraniczny. Mamy 2 gospodarstwa holenderskie, są Szkoci i Arabowie. Agencja nie chce dzierżawić ani sprzedawać ziemi polskim rolnikom".

Wszystkie fale nowoosadników tworzone były przez grupy (choć nie zawsze wewnętrznie jednorodne), które łączyła konieczność przetrwania i wspólnego zagospodarowania wsi. Współcześnie zarysowuje się wyraźny podział na tych, którzy przybyli tu dla „uroku tego miejsca" i tych, którzy mają wizję przekształcenia go w taki sposób, by przynosił im korzyści ekonomiczne. Wyraźne jest zjawisko tzw. gry o przestrzeń, prowadzonej głównie przez grupę osadników ostatniej, trzeciej fali. Przykładem rozbieżnych wizji rozwoju przestrzeni są działania właścicieli wielkoobszarowych gospodarstw rolnych nastawionych na intensywną produkcję rolniczą, związaną z silną eksploatacją lokalnych zasobów i planowane inwestycje budowy farm wiatrowych. Gospodarka tych podmiotów „ludziom z miasta" nie wydaje się korzystna:

„(...) Rabunkowa gospodarka jeśli chodzi o krajobraz - nie ma ani jednego drzewa. Krajobraz jest wyjałowiony".

Rozmówcy, w większości dostrzegający uroki życia na wsi, być może nieco idealizujący życie wiejskie, z żalem mówią o zmianach, jakim podlega współczesna wieś:

„Na niekorzyść zmienił się krajobraz gospodarstw wiejskich, np. wiejski weterynarz kiedyś obsługiwał wielkie ilości krów, a dziś zajmuje się pieskami. Hodowli terenowych (krów na łące) nie ma w tych okolicach. Są 2-3 gospodarstwa mięsne w Koszkowach i Marzęcinie. Jedno z nich jest holenderskie".

Badani wykazują troskę o ochronę przyrody i zachowanie wiejskiego charakteru i krajobrazu wsi. W kategoriach zagrożenia tych wartości postrzegają sąsiada - (kolejnego) Holendera, który wykupił część PGR (ok. 700 ha):

„Na tym terenie wycięto ok. 300 drzew, a zgłoszonych do wycięcia było tylko 10. Żadne instytucje tego problemu nie rozwiązują. Jest to łakomstwo. Tego nie wolno byłoby zrobić w Holandii".

Nowoosadnicy poszukują także rozwiązań stwarzających namiastkę dawnych cech wiejskości, która ma być atutem wybranego przez nich miejsca do życia:

„Nieliczni mali gospodarze mają krowy, powoli zaczyna wchodzić moda na przydomową hodowlę kóz, kur. Może powstanie kiedyś taka inicjatywa społeczna, że mieszkańcy będą składać się na utrzymanie kilku zwierząt gospodarskich, które będzie hodował jeden mieszkaniec. A pozostali właściciele będą mogli z tego też korzystać". 
O zaangażowaniu w sprawy dotyczące wsi i umiejętności rozwiązywania problemów (elementach tworzących potencjał społeczności) świadczy szereg kolejnych przykładów. Mieszkańcy śledzą bowiem bacznie przepisy, które zmierzają do coraz większej ochrony przyrody i zgłaszają nadużycia:

„(...) od tego roku weszły w życie przepisy dotyczące dopłaty dla posiadaczy areałów/gospodarstw posiadających powyżej 15 ha, które wskazują na konieczność zazielenienia, tj. pewna część gruntów musi być przeznaczona pod miedzę, krzaki. Stada saren nie mają gdzie żerować".

Badani obawiają się gospodarki rabunkowej, sprzecznej z ich wizjami rozwoju wsi i wartościami. Sprzeciwiają się bezmyślnemu, w ich przekonaniu, szpeceniu krajobrazu, który jest tak cenną wartością ziemi żuławskiej:

„Obszar chroniony krajobrazu Szkarpawy obejmuje 100 metrów od brzegu rzeki. Jeśli staniemy na 101 metrze możemy postawić wiatrak, którego wysokość przewyższa dwukrotnie tę odległość. Nie chroni się krajobrazu, tylko stosuje przepisy które mówią, że na 101 metrze możemy wszystko zbudować. Jest to jeden z tych elementów, które powodują, że nasze kulturowe wartości giną".

Wszyscy rozmówcy jednoznacznie potwierdzają, że mobilizacja dotychczas biernej społecznie wsi nastąpiła w momencie, gdy pojawiło się tzw. zagrożenie wiatrakowe:

„Wisi nad nami i powiatem 80 wiatraków”. Od tego momentu, jak mówi jeden z mieszkańców: „zostało scementowane poczucie wspólnego interesu”.

Działania przebiegały wielokierunkowo. Z jednej strony polegały na organizowaniu spotkań z mieszkańcami sołectwa, podczas których wymieniano informacje na temat potencjalnych zagrożeń. Co bardzo ważne, jak zaznacza jedna z kobiet relatywnie niedługo zamieszkująca we wsi, była to okazja do bezpośredniego poznania mieszkańców, nawiązania kontaktu i rozmowy, nie tylko na temat wiatraków. Inne działania zostały ukierunkowane na współpracę z władzami lokalnymi lub przeciwdziałanie ich projektom. Po pierwsze, chodziło o zasygnalizowanie sprzeciwu mieszkańców i przedstawienie własnych argumentów:

„Daliśmy znać naszym władzom, jakie tu są walory i żeby tego nie niszczyli”.

Działania „antywiatrakowe” przyniosły efekt w postaci zwiększonego poczucia podmiotowości, tj.

- wpływu na to, co dzieje się w gminie:

„Po raz pierwszy ze względu na Żuławki gmina poczuła, że ludzie czegoś konkretnego wymagają jako zbiorowisko (...)",

- i możliwości skutecznego wyrażenia sprzeciwu na poziomie administracji rządowej:

„Myślę, że zobaczył wtedy (wojewoda - podkr. aut.), że jest duży opór społeczny, ilość pism które do niego poszły, nasze wizyty itd. Zobaczył i musiał znaleźć coś, żeby cofnąć do gminy". 
W skład nowej rady gminy weszła mieszkanka Żuławek, do czego z pewnością przyczyniła się aktywność wyborcza mieszkańców sołectwa. Mobilizacja społeczności wzrosła, gdy spostrzeżono, że ze strony inwestora i niektórych radnych pojawił się opór i sprzeciw wobec postulatów mieszkańców:

„W międzyczasie liczba radnych, którzy byli przeciw, zaczęła topnieć. Nie zgłoszono więcej poprawek, tylko odstąpiono od przygotowania planu. (...) Inwestorem miała być firma holenderska i wybrała teren należący do Holendra, łatwiej było im porozumieć się i płacić tylko jednemu. (...) Myśmy przekonali radnych, żeby wystąpić z moratorium zakazu budowy wiatraków do czasu uchwalenia. Utrącono nam to".

Aby wspólne działania były skuteczne, niezbędna była nie tylko świadomość zagrożenia i chęć przeciwdziałania, ale także wiedza merytoryczna z zakresu postępowania administracyjnego i planowania przestrzennego:

„Czego nie wymagały te pierwsze nasze spotkania wiatrakowe, kiedy był zatwierdzony przez gminę plan zagospodarowania, wydawało się, że już absolutnie nic nie da się zrobić (...), różnego rodzaju błędy wytknęliśmy, (...) wojewoda nie zatwierdził, cofnął do gminy z powodu niezgodnie z prawem zrobionego rysunku - nie było linii rozgraniczających".

Zasoby te (np. wiedza, kontakty z adwokatami, specjalistami) mają właśnie nowoosadnicy. Są to z reguły ludzie dobrze sytuowani, wykształceni, posiadający znaczny kapitał społeczny i często relatywnie dużo wolnego czasu, który mogą i chcą poświęcić na działanie społeczne.

Charakterystyka działań społeczności Żuławek zaobserwowanych przez autorki prowadzi do wniosku, że wieś posiada znaczny potencjał do dalszego rozwoju. Jej członkowie angażują się we wspólne sprawy (i te o charakterze kulturalnym, jak i przestrzennym), umieją rozwiązywać lokalne problemy lub poszukiwać metod ich rozwiązania, a także, dzięki osadnikom trzeciej fali, uzyskali znacznie szerszy dostęp do zewnętrznych zasobów (finansowych czy informacyjnych).

\section{Funkcje i rezultaty potencjału, czyli wizje rozwoju turystyki w Żuławkach}

Przedstawiciele społeczności Żuławek wyraźnie artykułują chęć rozwoju funkcji turystycznej wsi, jednak w sposób planowy i kontrolowany, nie zaburzając jej obecnej specyfiki. Wizje cechują oryginalne, realne (tj. możliwe do realizacji) i zrównoważone pomysły na rozwój turystyki, opierającej się w głównej mierze na lokalnych zasobach przestrzenno-środowiskowych. Charakterystyczne jest jednak to, że nie kierują oczekiwań wyłącznie do władz lokalnych, lecz sami (jednostkowo lub grupowo) podejmują działania na rzecz poprawy szeroko rozumianej jakości życia w ich wsi i rozwoju całej miejscowości.

Pomysł na rozwój bazuje na wykorzystaniu położenia Żuławek (nad rzeką Szkarpawą, co pozwala korzystać z sieci dróg wodnych, w bliskim sąsiedztwie morza), zasobów architektonicznych miejscowości (domy podcieniowe, obiekty hydrotechniczne) istniejącej oferty pobytowej (przystań, wypożyczalnia kajaków, agroturystyka) i planowanej budo- 
wy ścieżki rowerowej. Na pytanie o cel przyjazdu turysty do Żuławek mieszkańcy wsi odpowiadają:

„(...) by być nad morzem, zbierać bursztyny i ten wypoczynek w gwarze i zgiełk plażowy połączyć z takim miejscem jak Żuławki".

Zatem pobyt w Żuławkach to dla turysty uzupełnienie lub alternatywa nadmorskiego zgiełku - spokojny wypoczynek nad rzeką w cichej, malowniczo położonej miejscowości. W tym znaczeniu Żuławki mogłyby się stać spokojną przystanią dla turysty. Badani mają świadomość potrzeby zróżnicowania oferty „dla klienta wymagającego i przeciętnego”, choć jasno określają, że ma być ona adresowana do tzw. „spokojnego turysty”. Nie chcą bowiem zniszczyć wiejskiej atmosfery tego miejsca nadmiernym ruchem turystycznym. Mieszkańcy są bardzo wrażliwi na zakłócanie spokoju i bezpieczeństwa. Nerwowo reagują na zbyt szybko jeżdżące samochody przez wieś i poszukują nowych rozwiązań tego problemu:

„Nie udało się wprowadzić dodatkowego utrudnienia w postaci wysepki zwalniającej, ale jest propozycja zamontowania świateł na skrzyżowaniu, które przy niskiej prędkości są zielone, a przy szybszej czerwone".

Problem stanowią także pędzące z nadmierną szybkością motorówki:

„Na Szkarpawie jest zakaz wślizgu tódek. Obowiązuje prędkość 8 km/h. Zmorą jest, gdy olbrzymia łódź płynie z prędkością 30-40km/h i robi metrową falę. Niszczy się wówczas cały sprzęt zacumowany".

Wizje rozwoju turystki podążają w dwóch kierunkach: pierwszy to Żuławki jako ciekawe miejsce wypoczynku dla jednodniowego, „tranzytowego" turysty, drugi to stworzenie oferty pobytowo-noclegowej, w której Żuławki pełnią rolę przystani - punktu startowego do zwiedzania innych pobliskich miejscowości.

Część turystów dojeżdżających nad morze do znanych kurortów, jak np. Jantar, Stegna, Kąty Rybackie, Krynica Morska, przejeżdża w pobliżu lub przez Żuławki, dlatego jednym z pomysłów jest „zatrzymanie turysty w drodze nad morze” - chodzi o turystę, który popływa kajakiem, zwiedzi domy podcieniowe, w przyszłości zje obiad i pojedzie dalej. Podobny pomysł odnosi się do turystów pływających Szkarpawą, którzy mogą przycumować łodzie w przystani i zwiedzić miejscowość. Mieszkańcy proponują organizację wycieczek z Gdańska do Żuławek: „turyści wysiadają, zjadają i wracają”. Problemem są jednak źle ustawione godziny otwarcia śluz i mostów, które uniemożliwiają sprawne przedostanie się tam i z powrotem, a także brak w chwili obecnej oferty gastronomicznej.

Druga oś, wokół której może rozwijać się turystka, to stworzenie sypialni dla turystów, którzy w dzień chcieliby uprawiać turystykę wodną, agroturystykę lub turystykę wiejską lub uczestniczyć w różnych wycieczkach wodnych, które mają start i metę w Żuławkach. Już dziś możliwe jest płynięcie własną łodzią lub wyczarterowanie jej we wsi. Mieszkańcy proponują m.in. wycieczkę do Gdańska, gdzie znajdują się teraz główne ośrodki żeglarskie, cykl wycieczek jednodniowych (rano wypłynąć, wieczorem powrócić) na Zalew Wiślany do Kątów Rybackich, Elbląga, Tczewa lub dwudniowych do Malborka. Ciekawym, 
lecz adresowanym do bardziej zamożnych turystów, jest pomysł wyczarterowania łodzi na tydzień, które pokonują Pętlę Żuławską. Obecnie, jak zauważają respondenci, można takimi wyczarterowanymi łódkami płynąć bez dodatkowych uprawnień. Również możliwa jest wycieczka z przewodnikiem. Atrakcją może być także wędkarstwo. W Szkarpawie żyją praktycznie wszystkie polskie ryby, m.in. boleń, szczupak, węgorz.

W rozmowach z respondentami pojawiała się także propozycja wodno-rowerowa, która zakłada, że turyści przywiozą ze sobą (np. na łodziach) rowery, a w Żuławkach przesiądą się na nie i będą dalej zwiedzać okolice. Pomysł będzie możliwy do zrealizowania dopiero, gdy pojawią się drogi rowerowe. Ciekawa może być wycieczka rowerowa do Rybiny (ok. 12 km), po obu stronach Szkarpawy, gdzie można zobaczyć liczne zabytkowe budowle. Droga ma obecnie charakter „nieoficjalny”, wiodąca tamtędy rowerowa trasa transeuropejska jest w planach. W pobliżu Żuławek znajduje się także unikatowy rezerwat przyrody Mewia Łacha z dużą liczbą fok. Niedaleko wsi, nad Szkarpawą, odbudowana została (wg oryginalnej metody, tj. bez użycia gwoździ) stara warownia.

W chwili prowadzenia badań mieszkańcy Żuławek szykowali się do zmiany treści studium uwarunkowań i kierunków zagospodarowania przestrzennego wsi, w którym ważne miejsce ma zajmować zapis o poszanowaniu krajobrazu. Ponadto w planach było utworzenie parku kulturowego, co z jednej strony podniesie atrakcyjność turystyczną miejscowości i zapewni jej ochronę:

„Park kulturowy nie oznacza, że musimy cofnąć się do Mieszka, przecież PGR to też historia, w takich budynkach po wewnętrznej rewitalizacji można zrobić szereg ciekawych rzeczy, np. stanicę dla rowerów",

z drugiej jednak budzi obawy miejscowej ludności (np. ze względu na władztwo konserwatora).

\section{Zakończenie}

Identyfikacja elementów potencjału społeczności lokalnej nie jest zadaniem łatwym. Jednak dwutygodniowe badania - pobyt w roli turysty w miejscowości Żuławki - dostarczyły wiele cennych spostrzeżeń i pozwoliły wydobyć niewidzialne lub trudne do uchwycenia elementy funkcjonowania tej społeczności.

Współcześni mieszkańcy Żuławek z racji stosunkowo niedługiego zamieszkiwania na tym terenie nie są mocno zakorzenieni w miejscowości, a poczucie tożsamości i identyfikacji z miejscem zamieszkania dopiero się w nich kształtuje. W przypadku nowoosadników ostatniej fali dominują więzi z tzw. wyboru (dobrowolnie wybrali to miejsce do zamieszkania) i o charakterze instrumentalnym. Natomiast potomkowie przesiedleńców z końca II wojny światowej przejawiają nieco większy stopień psychicznego zespolenia. Potwierdzenie tych tez znajdziemy w samoidentyfikacji wyrażanej w sformułowaniach: „my nie jesteśmy stąd”, ale i np. w wierszach nieżyjącej już lokalnej poetki, która pisze o tym miejscu jako własnym i ukochanym. Pewien rodzaj poczucia wspólnoty przejawia się w konfrontacji z nowymi, zagranicznymi dużymi przedsiębiorcami/farmerami, którzy mają inną, zdaniem respondentów rabunkową wizję korzystania z przestrzeni wsi i gminy. W tej grze o przestrzeń mieszkańcy czują się odpowiedzialnymi gospodarzami, niezależnie od długości zamieszkiwania. 
Nieco inaczej (posiadają bowiem bardziej wyraziste cechy) kształtuje się drugi i trzeci element potencjału - zaangażowanie we wspólne sprawy oraz umiejętność rozwiązywania problemów. Przybysze z miasta wspólnie zaangażowali się w działania na rzecz ochrony krajobrazu, bezpieczeństwa, tworzenia dokumentów urzędowych, strategicznych i tzw. „walki z wiatrakami”, by chronić wartości, które przyciągnęły ich do tej miejscowości. Jednostkowo również podejmują aktywność, np. na płaszczyźnie lokalnej przedsiębiorczości (wypożyczalnia kajaków, domki letniskowe, przystań). Pozostali są nieco mniej aktywni na arenie politycznej i społeczno-środowiskowej, chętniej uczestniczą w spotkaniach integracyjnych i kulturalnych. Na uwagę zasługuje aktywność młodzieży w pracach porządkowych i społecznych organizowanych przez sołtysa. Podmiotowość badanej społeczności przejawia się w zdolności angażowania się na rzecz wsi, samodzielnej identyfikacji atutów, ograniczeń i wizji rozwoju tego miejsca, artykulacji potrzeb społeczności, aktywizacji otoczenia na rzecz realizacji ustalonych planów. Mieszkańcy czują się uprawnionymi do zrównoważonego korzystania z lokalnych zasobów gospodarzami tego terenu. Świadczy o tym m.in. zgłaszanie potrzeb sołectwa podczas sesji czy zebrań organizowanych w gminie.

Szczególne miejsce w tych działaniach zajmuje turystyka (choć według respondentów wiodącą w miejscowości powinna być funkcja mieszkalna). Miejscowość Żuławki dysponuje uwarunkowaniami środowiskowymi, które pozwalają na jej rozwój. Są to: położenie, krajobraz, historia, architektura, rzeka, a także zalążki infrastruktury pobytowej (przystań wodna, wypożyczalnia kajaków czy oferta domków letniskowych). Społeczność nie poprzestaje na już istniejących walorach, stara się je chronić, ale również współtworzyć powstawanie nowych. Szczególnie doniosłą rolę pełnią osadnicy ostatniej fali. Cechując się relatywnie wysokim poziomem kapitału ludzkiego i społecznego (funkcjonując także w wielu sieciach poza miejscem zamieszkania), korzystają z zasobów zewnętrznych (takich jak doradztwo, informacja itp.) i wykorzystują go na rzecz rozwoju miejscowości.

Prowadząc badania, trudno było zidentyfikować jedną osobę, która byłaby zdecydowanym liderem lokalnej społeczności. Każdy obszar aktywności miał swego przywódcę: sołtys aktywizuje społecznie i kulturalnie młodzież i mieszkańców, ważną rolę odgrywają również przedsiębiorcy: właściciel przystani walczy o ochronę krajobrazu i jest „duszą” żeglugi w Żuławkach, zaś radna dba o interesy sołectwa na arenie gminy, reaktywuje lokalne stowarzyszenie, posiada doświadczenie w zdobywaniu zewnętrznych środków finansowych i remontuje stary dom podcieniowy, który zamierza udostępnić turystom.

Potencjał wsi to zdolność do jej rozwoju, a zatem cecha, która może stanowić o tym, czy wieś się rozwija. Samo posiadanie jej nie daje gwarancji, że ten proces nastąpi. Aby potencjał został „wyzwolony”, do działania powinny zaistnieć jeszcze co najmniej dwa warunki. Pierwszy - społeczność musi wyartykułować i podzielać chęć dążenia do wspólnego dobra, drugi - musi zaistnieć szczególna okoliczność wyzwalająca potencjał do realnego działania. Oba kryteria spełnia społeczność Żuławek. Bodziec, jakim stała się tzw. „walka z wiatrakami”, wyzwolił w niej wolę współdziałania na rzecz własnego miejsca zamieszkania i ochrony jego dziedzictwa zarówno przyrodniczego, jak i kulturowego. Chęci przerodziły się w konkretne działania (prowadzenie niewielkiej działalności gospodarczej związanej z usługami turystycznymi, protest przeciw budowie wiatraków, reaktywacja lokalnego stowarzyszenia) oraz stworzenie wizji/planu zrównoważonego rozwoju Żuławek (uczestnictwo w pracach nad planami strategicznymi gminy). Zrówno- 
ważenie wyraża się w takim rozwoju miejscowości, by turystyka przynosiła mieszkańcom zyski finansowe, lecz nie zniekształciła funkcji rolniczej czy mieszkalnej tego miejsca. Gwarantem ma być ochrona krajobrazu kulturowego Żuławek i okolic, m.in. poprzez utworzenie we wsi parku kulturowego. Można zaryzykować stwierdzenie, że członkowie społeczności wykazują nieco większą troskę o ochronę przyrody niż dziedzictwa kulturowego. Wydaje się, że te wartości są dla nich ważniejsze. Mimo to, dysponując potencjałem do samoorganizacji, przejawiają dużą aktywność na rzecz miejsca, które wybrali do życia.

Społeczność wsi Żuławki stoi na początku drogi zmierzającej do jej rozwoju i przemian z rolniczej, popegeerowskiej w kierunku turystyczno-mieszkaniowej. Trudno zatem na dzień dzisiejszy ocenić rezultaty podejmowanych działań. Z całą pewnością jednak można stwierdzić, że posiada ona znaczny potencjał, który ma szansę dalej się rozbudowywać i sprzyjać poprawie warunków i jakości życia mieszkańców, także rozwijając na tym terenie zrównoważoną turystykę.

\section{Literatura}

Broniarek W., 2005, Gdy ci słowa zabraknie, Haroldson Press, Brwinów.

Chaskin R.J., Brown P., Venkatesh S., Vidal A., 2001, A Building Community Capacity, Aldine de Gruyter, New York.

Chaskin R.J., Brown P., Venkatesh S., Vidal A., 2007, Budowanie potencjału społeczności lokalnej, [w: T. Kazimierczak (red.), Zmiana w społeczności lokalnej. Szkice o kapitale społecznym w praktyce społecznej i nie tylko, Instytut Spraw Publicznych, Warszawa, s. 37-72.

Coleman J., 1988, Social capital in the creation of human capital, American Journal of Sociology, 94, s. 95-120.

Etzioni E., 2012, Aktywne społeczeństwo: teorie procesów społecznych i politycznych, Zakład Wydawniczy Nomos, Kraków.

Jeziorska-Biel P., Marks-Krzyszkowska M., 2017, „Przystań prawdziwych wartości” - Żuławki, [w:] M. Wójcik (red.), Tożsamość i „miejsce”. Budzenie uśpionego potencjału wsi, Wydawnictwo Uniwersytetu Łódzkiego, Łódź, s. 21-27.

Lewenstein B., 2006, Nowe paradygmaty rozwoju układów lokalnych - w stronę obywatelskiej wizji społeczności lokalnych, [w:] J. Kurczewska (red.), Oblicza lokalizmu. Różnorodność miejsc i czasu, IFIS, Warszawa, s. 221-245.

Lipińska B., 2011, Żuławy Wiślane - ochrona i kształtowanie zabytkowego krajobrazu, Stowarzyszenie Żuławy, Nowy dwór Gdański, Gdańsk.

McMillan D.W., Chavis D.M., 1986, Sence of community: A definition and theory, Journal of Community Psychology, 14 (1), s. 6-23.

Michalska-żyła A., 2010, Psychospołeczne więzi mieszkańców z miastem. Studium na przykładzie Łodzi, Wydawnictwo Uniwersytetu Łódzkiego, Łódź.

Putnam R., 1993, The prosperous community: Social capital and public life, American Prospect, 13, s. $35-42$.

Starosta P., 1995, Poza metropoliq, Wydawnictwo Uniwersytetu Łódzkiego, Łódź.

Wieruszewska M., 2014, Myślenie o wsi i regionie w kategorii wspólnoty: anachronizm czy aktualna perspektywa? Wieś i Rolnictwo, 1/162, s. 139-53. 
Wójcik M., 2016, Uwarunkowania tworzenia „Sieci Najciekawszych Wsi”. Wyniki oceny eksperckiej 50 polskich miejscowości, Acta Universitaties Lodziensis Folia Geographica Socio-oeconomica, 25, s. 109-129.

\section{Summary}

The aim of this article is to identify the potential of local communities in tourism development in the countryside. The exemplification of the discussion is the creation of rural tourism development in the village called Zulawki in Stegna commune. The village has landscape and natural values and a convenient spatial location. However, the authors wish to draw particular attention to the process of self-activation observed among the influx community for sustainable development of the village. It is possible owing to the emerging features of the potential of this community: mutual integration, commitment, problem solving orientation and access to resources. The subjectivity of the characterised community manifested itself in the ability to adapt and identify with the new place of residence and its problems, drive to articulate one's own vision of rural development, and activation of the environment for the implementation of established plans. The text is based on the results of a study conducted in 2015 by means of participatory observation techniques and free-form interviews with local activists. 
http://rcin.org.pl 